\title{
UJI EFEK HIPOGLIKEMIK EKSTRAK KLOROFORM DAN n-BUTANOL DAUN BELIMBING WULUH (Averrhoa bilimbi L.) PADA MENCIT (Mus musculus) YANG DIINDUKSI ALOKSAN
}

\author{
Rachmat Kosman \\ Fakultas Farmasi Universitas Muslim Indonesia \\ Email : rachmatkosman@gmail.com
}

\begin{abstract}
The research About, Hypoglycemic Effect Test Extracts Chloroform and nButanol Leaf Belimbing Wuluh (Averrhoa bilimbi L.) Against Mice (Mus musculus) The Induced by Aloksan. This absorvation is done withaim to determine the hypoglycemic of test chloroform and $n$-butanol leaf belimbing wuluh (Averrhoa bilimbi L.) against mice (Mus musculus) with the main aloksan. This animal abservatian try to inductied. With aloction with the aim to destroy sel- $\beta$ pancreas and try to rise the animal blood glucose rate. This research utilized 18 male mice divided into 6 groups, each group consisted of 3 male mice. Groop I was given 0,182 gram $/ \mathrm{kgBB}$ of chloroform extract, groop II was given 0,091 gram/kgBB chloroform extract, groop III was given 0,182 gram $/ \mathrm{kgBB}$-butanol extract and groop IV was given 0,091 gram $/ \mathrm{kgBB}$ n-butanol extract, and groop $V$ was the positif comparison groop that given glybenclamide sespention and groop $\mathrm{VI}$ is the groop with negative control that was given Na CMC 1\%. It was given by feeded with volume of $1 \mathrm{ml} 30 \mathrm{gBB}$. The abservatian reault shaw that chloroform ekstrak and $n$-butanol belimbing wuluh leat (Averrhoa bilimbi L.) has the effect to deerease glucose blood to mice (Mus musculus).
\end{abstract}

Key Words : Hipoglycemic, Avverhoa bilimbi, Aloxan

\section{PENDAHULUAN}

Diabetes Mellitus (DM) atau disingkat diabetes adalah gangguan kesehatan yang berupa kumpulan gejala yang disebabkan oleh peningkatan kadar gula (glukosa) darah akibat kekurangan ataupun resistensi insulin. Penyakit ini sudah lama dikenal, terutama di kalangan keluarga "berbadan besar" (kegemukan) bersama dengan gaya hidup "tinggi". Kenyatanya kemudian, DM menjadi penyakit masyarakat umum, menjadi beban kesehatan masyarakat, meluas dan membawa banyak kematian (Bustan, 2007).

Diantara penyakit degeneratif, diabetes adalah salah satu diantara penyakit tidak menular yang akan 
Uji Efek Hipoglikemik Ekstrak Kloroform Dan n-Butanol Daun Belimbing Wuluh Pada Mencit Yang Diinduksi Aloksan

meningkat jumLahnya dimasa akan datang. WHO membuat perkiraan bahwa pada tahun 2000 jumLah pengidap diabetes di atas umur 20 tahun berjumLah 150 juta orang dan dalam kurun waktu 25 tahun kemudian, pada tahun 2025, jumLah itu akan membengkak menjadi 300 juta orang (Sudoyo, 2006).

Penyakit diabetes biasanya disebabkan oleh dua faktor utama. Pertama adalah faktor kelebihan mengonsumsi gula, makanan berlemak dan kolesterol, namun rendah serat dan vitamin. Faktor kedua adalah keturunan. Namun, faktor usia dan kegemukan juga sangat berpengaruh. Faktanya lebih dari $90 \%$ penderita diabetes tipe serangan dewasa adalah penderita obesitas/kegemukan, gaya hidup yang tidak sehat dan pola makan yang tidak baik menyebabkan tidak adanya keseimbangan antara karbohidrat dan kandungan lain yang dibutuhkan oleh tubuh. Akibatnya kandungan gula dalam tubuh juga tinggi melebihi kapasitas kerja pangkreas (Sudoyo, 2006).

Bangsa Indonesia telah lama mengenal dan menggunakan tanaman berkhasiat obat sebagai salah satu upaya dalam menanggulangi masalah kesehatan. Pengetahuan tentang tanaman berkhasiat obat berdasar pada pengalaman dan keterampilan yang secara turun temurun telah diwariskan dari satu generasi ke generasi berikutnya (Oktora, 2006).

Banyak tanaman yang dapat berfungsi sebagai obat antidiabetes. Salah satu obat tradisional yang sering digunakan oleh masyarakat sebagai obat antidiabetes adalah bilimbing wuluh (Averrhoa bilimbi L.). Tanaman tersebut secara empiris mempunyai khasiat untuk pengobatan penyakit diabetes melitus. Sebagai bahan obat yang digunakan adalah rebusan daun bilimbing wuluh.

Berdasarkan uraian di atas maka dilakukan penelitian untuk mengetahui efek Bilimbing Wuluh (Averrhoa bilimbi L) dalam mengobati penyakit diabetes.

\section{METODE PENELITIAN}

1. Alat dan Bahan ;

Alat dan bahan penelitian
disiapkan sesuai dengan
kebutuhan.

2. Pemilihan dan Penyediaan Hewan Uji ;

Hewan uji yang digunakan adalah mencit (Mus musculus) yang sehat dengan bobot badan 20-30 g, digunakan 15 ekor yang dibagi dalam 3 kelompok dan tiap 
Uji Efek Hipoglikemik Ekstrak Kloroform Dan n-Butanol Daun Belimbing Wuluh Pada Mencit Yang Diinduksi Aloksan

kelompok terdiri atas 3 ekor mencit, yang terlebih dahulu diadaptasikan selama dua minggu dan di berikan makan dan minum yang sesuai.

3. Perlakuan Terhadap Hewan Uji ;

Sebelum perlakuan mencit dipuasakan selama 8 jam kemudian ditimbang berat badannya dan diukur kadar glukosa darah puasa. Setelah itu diinduksi aloksan secara intraperitonial $120 \mathrm{mg} / \mathrm{kg} \mathrm{BB}$. Setelah 2 hari di ukur kadar glukosa darah awal, diberikan perlakuan yang sama untuk semua kelompok. Kelompok I,II,III, dan IV diberi ekstrak kloroform 0,182 gram $/ \mathrm{kgBB}, 0,091 \mathrm{gram} / \mathrm{kgBB}$ dan n-butanol 0,182 gram/kgBB, 0,091 gram $/ \mathrm{kgBB}$ sesuai dengan volume pemberian, kelompok $\mathrm{V}$ diberi glibenklamid sebagai kontrol positif dan kelompok VI diberi NaCMC sebagai kontrol negatif sesuai dengan volume pemberian, setelah itu pengukuran kadar glukosa darah selama 4 jam setelah pemberian obat dengan pengukuran setiap interval 1 jam.

\section{Penentuan Kadar Gula ;}

Kadar gula darah pada mencit di ukur dengan cara ujung ekor mencit di potong kemudian darahnya diteteskan pada strip yang sudah dimasukkan ke alat glukometer, yang akan membaca kadar gula darah pada mencit.

\section{HASIL PENELITIAN}

Tabel 1. Hasil penggukuran kadar glukosa darah mencit.

\begin{tabular}{|c|c|c|c|c|c|c|c|}
\hline \multirow{2}{*}{ Perlakuan } & \multirow{2}{*}{ Mencit } & \multicolumn{5}{|c|}{ Kadar Glukosa Darah (Mg/dl) Pada Jam Ke } & \multirow{2}{*}{ Nilai } \\
\hline & & Awal & 1 & 2 & 3 & 4 & \\
\hline \multirow{5}{*}{ Kelompok I } & 1 & 150 & 164 & 118 & 107 & 89 & 61 \\
\hline & 2 & 97 & 98 & 92 & 104 & 80 & 17 \\
\hline & 3 & 85 & 87 & 100 & 106 & 86 & -1 \\
\hline & $\sum \mathbf{X}$ & 332 & 349 & 310 & 317 & 255 & 77 \\
\hline & $X$ & 110.67 & 116.33 & 103.33 & 105.67 & 85.00 & 25.667 \\
\hline \multirow{5}{*}{ Kelompok II } & 1 & 521 & 279 & 252 & 177 & 76 & 445 \\
\hline & 2 & 78 & 98 & 81 & 60 & 47 & 31 \\
\hline & 3 & 78 & 81 & 75 & 67 & 53 & 25 \\
\hline & $\sum \mathbf{X}$ & 677 & 458 & 408 & 304 & 176 & 501 \\
\hline & $X$ & 225.67 & 152.67 & 136.00 & 101.33 & 58.67 & 167 \\
\hline \multirow{5}{*}{ Kelompok III } & 1 & 98 & 105 & 80 & 59 & 55 & 43 \\
\hline & 2 & 80 & 80 & 75 & 68 & 52 & 28 \\
\hline & 3 & 80 & 112 & 99 & 81 & 58 & 22 \\
\hline & $\sum \mathbf{X}$ & 258 & 297 & 254 & 208 & 165 & 93 \\
\hline & $X$ & 86.00 & 99.00 & 84.67 & 69.33 & 55.00 & 31 \\
\hline \multirow{5}{*}{ Kelompok IV } & 1 & 177 & 229 & 209 & 167 & 160 & 17 \\
\hline & 2 & 150 & 171 & 95 & 92 & 79 & 71 \\
\hline & 3 & 100 & 112 & 99 & 93 & 84 & 16 \\
\hline & $\sum \mathbf{X}$ & 427 & 512 & 403 & 352 & 323 & 104 \\
\hline & $X$ & 142.33 & 170.67 & 134.33 & 117.33 & 107.67 & 34.667 \\
\hline
\end{tabular}


Uji Efek Hipoglikemik Ekstrak Kloroform Dan n-Butanol Daun Belimbing Wuluh Pada Mencit Yang Diinduksi Aloksan

\begin{tabular}{|c|c|c|c|c|c|c|c|}
\hline \multirow{5}{*}{ Kelompok V } & 7 & 499 & 436 & 402 & 311 & 185 & 314 \\
\hline & 2 & 105 & 65 & 55 & 50 & 46 & 59 \\
\hline & 3 & 105 & 66 & 60 & 55 & 44 & 61 \\
\hline & $\sum \mathbf{X}$ & 709 & 567 & 517 & 416 & 275 & 434 \\
\hline & $X$ & 236.33 & 189 & 172.3 & 138.67 & 91.67 & 144.66 \\
\hline \multirow{5}{*}{ Kelompok VI } & 1 & 112 & 130 & 106 & 88 & 90 & 22 \\
\hline & 2 & 105 & 98 & 102 & 95 & 95 & 10 \\
\hline & 3 & 122 & 130 & 118 & 116 & 118 & 4 \\
\hline & $\sum \mathbf{X}$ & 339 & 358 & 326 & 299 & 303 & 36 \\
\hline & $\mathbf{X}$ & 113 & 119.33 & 108.67 & 99.67 & 101.00 & 12 \\
\hline
\end{tabular}

Keterangan :

1. Kelompok I : Ekstrak kloroform Averrhoa bilimbi L. 0,182 g/kgBB

2. Kelompok II : Ekstrak kloroform Averrhoa bilimbi L. $0.091 \mathrm{~g} / \mathrm{kgBB}$

3. Kelompok III : Ekstrak n-butanol Averrhoa bilimbi L. 0,182 g/kgBB

4. Kelompok IV : Ekstrak n-butanol Averrhoa bilimbi L. 0,091 g/kgBB

5. Kelompok V : Suspensi glibenklamid

6. Kelompok VI : Suspensi Na CMC

Tabel 2. Penurunan kadar glukosa darah $(\mathrm{mg} / \mathrm{dL})$

\begin{tabular}{llccc}
\hline \multirow{2}{*}{ No } & \multicolumn{1}{c}{ Perlakuan } & \multicolumn{2}{c}{$\begin{array}{c}\text { Kadar glukosa darah } \\
\text { Rata-rata (mg/dL) }\end{array}$} & \multirow{2}{*}{$\begin{array}{c}\text { Penurunan kadar } \\
\text { glukosa darah } \\
\text { (mg/dL) }\end{array}$} \\
\cline { 3 - 4 } & Awal & Jam ke 4 & \\
\hline 1 & $\begin{array}{l}\text { Ekstrak Kloroform Daun Belimbing } \\
\text { Wuluh 0,182 Gram/Kg Bb }\end{array}$ & 110.67 & 102.58 & 8.09 \\
\hline 2 & $\begin{array}{l}\text { Ekstrak Kloroform Daun Belimbing } \\
\text { Wuluh 0,091 Gram/Kg Bb }\end{array}$ & 225.67 & 112.17 & 113.50 \\
\hline 3 & $\begin{array}{l}\text { Ekstrak N-Butanol Daun Belimbing } \\
\text { Wuluh 0,182 Gram/Kg Bb }\end{array}$ & 86.00 & 77.00 & 9.00 \\
\hline 4 & $\begin{array}{l}\text { Ekstrak N-Butanol Daun Belimbing } \\
\text { Wuluh 0,091 Gram/Kg Bb }\end{array}$ & 142.33 & 132.50 & 9.83 \\
\hline 5 & Suspensi Glibenklamid & 236.33 & 147.92 & 88.41 \\
\hline 6 & Suspensi Na CMC & 133.00 & 104.92 & 28.08 \\
\hline
\end{tabular}

\section{PEMBAHASAN}

Penelitian ini dilakukan untuk menentukan pengaruh ekstrak kloroform dan $\mathrm{n}$-butanol daun bilimbing wuluh (Averrhoa bilimbi L.) terhadap penurunan kadar glukosa darah mencit jantan yang sebelumnya diinduksi dengan aloksan untuk meningkatkan kadar glukosa darah.

Hewan yang digunakan dalam penelitian ini adalah mencit (Mus musculus) yang berjenis kelamin jantan, dalam kondisi sehat. Mencit betina tidak digunakan karena sistem hormonalnya tidak stabil dibandingkan dengan mencit jantan. Walaupun demikian, faktor variasi biologis dari hewan uji tidak dapat dihilangkan sehingga dapat mempengaruhi hasil penelitian oleh karena itu terdapat perbedaan kosentrasi darah awal untuk tiap hewan coba. Sebelum perlakuan mencit dipuasakan terlebih dahulu \pm 8 jam dengan maksud untuk meminimalkan pengaruh makanan 
Uji Efek Hipoglikemik Ekstrak Kloroform Dan n-Butanol Daun Belimbing Wuluh Pada Mencit Yang Diinduksi Aloksan

pada pengukuran kadar glukosa darah.

Pada pengukuran kadar glukosa menggunakan alat glukometer dimana mekanisme kerjanya yaitu tetesan darah yang mengandung glukosa akan bereaksi dengan glukosa oksidase yang terkandung dalam strip dan akan merubah warna strip, warna yang dihasilkan berbeda-beda. Intensitasnya warnanya sesuai dengan jumLah glukosa yang terdapat pada darah dan diukur secara fotometik.

Pemberian larutan aloksan pada mencit dilakukan $2 \times 24$ jam sebelum perlakuan dengan tujuan untuk menaikkan kadar glukosa darah mencit dengan merusak sel-sel $\beta$ pangkreas. Aloksan bereaksi dengan merusak substansi esensial didalam sel beta pankreas sehingga menyebabkan berkurangnya granula granula pembawa insulin didalam sel beta pankreas. Aloksan meningkatkan pelepasan insulin dan protein dari sel beta pankreas tetapi tidak berpengaruh pada sekresi glukagon.

Pembanding antidiabetik oral yang digunakan dalam penelitian ini adalah glibenklamid dengan mekanisme kerja menstimulasi penglepasan insulin yang tersimpan (stored insulin) dan meningkatkan sekresi insulin akibat rangsangan glukosa.

Setelah dilakukan pengukuran kadar glukosa darah selama 4 jam, diperoleh nilai rata-rata penurunan glukosa yang dapat dilihat pada (tabel 2), kemudian dilanjutkan pada uji Wilcoxon test untuk mengukur perbedaan kadar glukosa sebelum dan setelah perlakuan (t4 dan t0).. Hasil analisisnya menunjukkan data yang $t 4$ $<\mathrm{t} 0=17$, artinya terdapat 17 data yang $t$ akhir lebih kecil dari pada data $t$ awal, dan pada data $\mathrm{t} 4>\mathrm{t} 0=0$ artinya tidak terdapat data yang $t$ akhir lebih besar dari pada $t$ awal.

Data selanjutnya dianalisis dengan menggunakan ANOVA untuk melihat perbedaan antar kelompok diperoleh nilai signifikansi sebesar 0,512, $(P>0,05)$, menunjukan tidak adanya perbedaan antara tiap kelompok, tidak terjadi perbedaan penurunan antara kelompok, kontrol, pembanding dan sampel. Jika dilihat dari individu hewan coba terlihat bahwa data panurunan yang dihasilkan hewan coba memiliki kesamaan yang dimana terbagi pada daerah 70-90 g/dL, sehingga dengan analisis tersebut tidak menghasilkan hasil yang berbeda. Karena hasil yang diperoleh tidak signifikan, maka 
Uji Efek Hipoglikemik Ekstrak Kloroform Dan n-Butanol Daun Belimbing Wuluh Pada Mencit Yang Diinduksi Aloksan

analisis Post Hoc Tests tidak dilanjutkan.

\section{KESIMPULAN}

Berdasarkan hasil penelitian maka dapat disimpulkan bahwa ekstrak kloroform dan n-butanol daun bilimbing wuluh (Averrhoa bilimbi L.) pada konsentrasi 0,091 gram/kg BB dan 0,182 gram $/ \mathrm{kg} \quad$ BB dapat menurunkan kadar glukosa darah.

\section{DAFTAR PUSTAKA}

Anonim. 2008. Referensi Kesehatan Diabetes Melitus (Internet). http://creasoft.wordpress.com /dibetes mellitus.

BPOM. 2004. Info POM. Vol. 5 : Jakarta

Bustan, M.N. 2007. Epidemiologi Penyakit Tidak Menular. Rineka Cipta: Jakarta.

Dalimartha. Setiawan. 1999. Atlas Tumbuhan Obat Indonesia, Trubus Agriwidya, Ungaran.

Dalimartha. Setiawan. 2008. Atlas Tumbuhan Obat Indonesia Jilid 5, Pustaka Bunda, Depok.

Departemen Kesehatan RI. 1986. Sediaan Galenik, Jakarta

Departemen Kesaehata RI. 1989. Materia Medika Jilid V, Jakarta.

Dirjen POM. 2006. Monografi Tumbuhan Obat Indonesia Vol.2.Badan Pengawasan Obat dan Makanan RI, Jakarta.

Gunawan, Sulistia Gan. 2008. Farmakologi dan Terapi. Edisi 5. Balai Penerbit FKUI: Jakarta.

Heyne, K. 1987. Tumbuhan berguna Indonesia, laporan kariyawan depertemen kehutanan Jakarta

Ismawan, B. 2010. Herbal Indonesia Berkhasiat. PT Trubus Swadaya Depok

Jasin. M dan Soemkari, 1992. Zoologi Vertebrata Untuk Perguruan Tinggi. PT. Antariksa: Surabaya.

Joseph T. Dipiro, et al. 2006. Pharmacotherapy Principles \& Practice. The McGraw-Hill Companies, Asia

Katzung.G.B. Farmakologi Dasar Dan Klinik. 2002. Salemba Medika, Jakarta

Lenzen S. 2008. The mechanism of alloxan and streptozotocin induceddiabetes, (Internet)htt p://www.ncbi.nlm.nih.gov/pub $\mathrm{med} / 18087688$ ?ordinalpos $=1$ \&itool=EntrezSystem2.PEntr ez.Pubmed.Pubmed Results Panel.Pubmed DiscoveryPa nel.Pubmed Discovery RA\&l inkpos $=4 \& \log \$=$ relatedreview s\&logdbfrom=pub diakses mei 2011

Malole. 1989. Penggunaan HewanHewan Percobaan Di Laboratorium, IPB, Bogor

Muhlisah. 1989. Tanaman Obat Keluarga, Penebar Swadaya, Jakarta.

Mycek, M.J, dan Harvey R.A, dan Champe P.C. 2001. 
Uji Efek Hipoglikemik Ekstrak Kloroform Dan n-Butanol Daun Belimbing Wuluh Pada Mencit Yang Diinduksi Aloksan

Farmakologi

Ulasan

Bergambar, Widya Medika, Jakarta.

Oktora L. 2006. Pemanfaatan Obat Tradisional dengan Pertimbangan Manfaat dan Keamanan. Mjlh. IIm. Kefarm. (Online). (http:// jurnal.farmasi.ui.ac.idpdf2006 v03-n01lusia0301.pdf, diakses mei 2011).

Price SA dan Wilson LM. 2005. Patofisiologi konsep klinis proses - proses penyakit , Edisi 6. Volume 2, EGC, Jakarta.

PERKENI. 2002. Konsensus Pengelolaan Diabetes Melitus Tipe 2 di Indonesia. Semarang

Suharmiati. 2003. Pengujian bioaktifitas anti diabetes melitus tumbuhan obat, Cermin Dunia Kedokteran. (Internet).

http://www.kalbe.co.id/files/cd k/06 PengujianBioefekAntiDi abetes.pdf/ diakses juni 2011

Szkudelski T. 2008. The mechanism of alloxan and streptozotocin action in $B$ cells of the rat pancreas (Internet) www.ncbi.nlm.nih.gov/pubme $\mathrm{d} / 11829314$

Sloane, Ethel. 2003. Anatomi dan Fisiologi untuk Pemula. EGC : Jakarta.

Sudoyo, et al. 2006. Buku Ajar IImu Penyakit Dalam Edisi Keempat Jilid III. FKUI: Jakarta.

Thomas A.N.S. 1989. Tanaman Obat Tradisional, Kanisius, Yogyakarta. 